\title{
Polyoxometalate multi-electron transfer catalytic systems for water splitting
}

\author{
Jordan M. Sumliner, ${ }^{[\mathrm{a}]}$ Hongjin Lv, ${ }^{[\mathrm{a}]}$ John Fielden, ${ }^{[\mathrm{b}]}$ Yurii V. Geletii, ${ }^{[\mathrm{a}]}$ and Craig L. Hill*[a]
}

Keywords: Polyoxometalates / Water Splitting / Photochemistry / Supported Catalysts / POM-based Triad

KEYTOPIC: Solar Fuel Catalysts

The viable production of solar fuels requires a visible-light absorbing unit, a $\mathrm{H}_{2} \mathrm{O}$ (or $\mathrm{CO}_{2}$ ) reduction catalyst (WRC) and a water oxidation catalyst (WOC) that work in tandem to split water or reduce $\mathrm{CO}_{2}$ with $\mathrm{H}_{2} \mathrm{O}$ rapidly, selectively and for long periods of time. Most catalysts and photosensitizers developed to date for these triadic systems are oxidatively, thermally and/or hydrolytically unstable. Polyoxometalates (POMs) constitute a huge class of complexes with extensively tunable properties that are oxidatively, thermally and (over wide and adjustable $\mathrm{pH}$ ranges) hydrolytically stable. POMs are some of the fastest and most stable WOCs to date. This Microreview updates the very active POM WOC field, reports the first POM WRCs and initial selfassembling metal oxide semiconductor-photosensitizer-POM catalyst triad photoanodes. The complexities of investigating these POM systems, including but not limited to the study of POM-hydrated metal ion-metal oxide speciation processes, are outlined. The achievements and challenges in POM WOC, WRC and triad research are outlined.

\section{Introduction}

Measurements and models make it ever more certain that the planet will face a serious energy shortage as the availability of economically accessible fossil fuels fails to keep pace with global energy needs. ${ }^{[1]}$ Data and analysis also indicate that the environmental change caused by fossil fuel combustion will become increasingly problematic. Although green and alternative energy sources are rapidly becoming more available and less expensive, the net consumption of environmentally worrisome fossil fuel is not dropping significantly. Increases in both global population and average global standard of living paint a less-thanrosy picture for our energy future. ${ }^{[1 \mathrm{~b}, 1 \mathrm{~g}, 2]}$ Solar remains the most likely source of sustainable energy for the medium and longer-term future. The other renewable sources of energy, with the arguable exception of biofuels provided the energy production efficiency (photosynthesis and other efficiencies) can be significantly increased, will not likely be sufficient to power the planet. In addition, high density energy will be needed in enormous quantities moving forward; electricity and other sources of energy will not provide sufficient energy density for our major transportation needs (ships, aircraft). Unlike the production of solar electricity, which is a now a rapidly maturing technical area and a major and growing market sector, production of solar fuel is in its infancy.

[a] Department of Chemistry, Emory University, 1515 Dickey Drive, Atlanta, GA 30329, USA

Fax: +1 404-727-6076

E-mail: chill@emory.edu

http://www.chemistry.emory.edu/faculty/hill/

[b] School of Chemistry, University of East Anglia, Norwich Research Park, Norwich, NR4 7TJ, UK
The principal reactions for the generation of solar fuel are $\mathrm{H}_{2} \mathrm{O}$ splitting to produce $\mathrm{H}_{2}$ and $\mathrm{O}_{2}$ (eq. 1) and $\mathrm{H}_{2} \mathrm{O}$ splitting coupled to $\mathrm{CO}_{2}$ reduction (eq. 2). Technology is needed so both these processes can be driven by terrestrial sunlight and proceed with high rates and selectivity to the desired products. A factor in the slow rates observed for $\mathrm{H}_{2} \mathrm{O}$ oxidation by many systems is that it is a four-electron, four-proton process, hence the need for a catalyst that can facilitate the multiple proton-coupled electron transfer (PCET) processes with low activation barriers. ${ }^{[3]}$

$$
2 \mathrm{H}_{2} \mathrm{O}+\mathrm{h} v \rightarrow \mathrm{O}_{2}+\mathrm{H}_{2}
$$

$2 \mathrm{CO}_{2}+4 \mathrm{H}_{2} \mathrm{O}+\mathrm{hv} \rightarrow 2 \mathrm{CH}_{3} \mathrm{OH}+3 \mathrm{O}_{2}$

Our group is working on the three requisite areas for solar fuel generation: (1) structures that absorb as much terrestrial sunlight as possible providing long-lived charge-separated excited states; (2) $\mathrm{H}_{2} \mathrm{O}$ reduction catalysts (WRCs) as well as $\mathrm{CO}_{2}$ reduction catalysts; and (3) water oxidation catalysts (WOCs). The principle vehicles we, and now many other groups are using in the design, study and implementation of these 3 classes of functional structures are polyoxometalates (POMs) because this enormous and growing class of inorganic structures are accessible, tunable, inexpensive and very robust. ${ }^{[4]}$ POMs are carbon-free, thus stable to oxidative degradation. ${ }^{[5]}$ These metal-oxide-cluster polyanions are capable of accepting multiple electrons for reduction, and transition-metal containing POMs are capable of bearing multiple holes for oxidation. Our research on POM catalysts for multi-electronprocesses solar fuel related processes (water oxidation, water and $\mathrm{CO}_{2}$ reduction) is built on years of work developing and investigating POMs as catalysts for oxidation and other processes. ${ }^{[6]}$ There has been and is now extensive research and development on POM catalysts, and several POM-catalyzed processes involving organic substrates have been 
commercialized. ${ }^{[7]}$ These cluster polyanions are also stable to thermal degradation and stable to hydrolytic degradation over wide $\mathrm{pH}$ ranges that are dictated by the POM framework metals, and the structure of the polyanion unit itself. The POM framework metals range from $\mathrm{W}(\mathrm{VI}), \mathrm{Mo}(\mathrm{VI})$ and $\mathrm{V}(\mathrm{V})$, which form acid-stable polyanions to $\mathrm{Nb}(\mathrm{V})$ and $\mathrm{Ta}(\mathrm{V})$, which form base-stable polyanions.

In this Microreview we discuss two important POM-based WOCs that our group has studied and concerns over the stability of the well studied $\left[\mathrm{Co}_{4}\left(\mathrm{H}_{2} \mathrm{O}\right)_{2}\left(\mathrm{PW}_{9} \mathrm{O}_{34}\right)_{2}\right]^{10-} \mathrm{WOC}$, as well as recent molecular WOCs with organic ligands. Then, we highlight recent POM-based reduction catalysts and light-to-current-converting POM-containing triadic structures. We have also developed POMbased photosensitizers, ${ }^{[8]}$ but do not cover this chemistry here. These areas of research in our group are interlinked as we continue to develop light-driven water splitting based on polyoxometalates.

\section{WOCs}

A major challenge in the development of viable molecular multielectron transfer catalysts for use in solar fuel applications is their stability both during use and under quiescent conditions. Water oxidation catalysts, in particular, are challenging to develop. Here, we discuss WOCs based on organic ligands and those with POM ligands, and compare shared strengths and weaknesses.

\section{Molecular WOCs with organic ligands}

The last few years have seen a resurgence of interest in all types of WOC, and progress has been dramatic - the maximum reported turnover frequency for molecular WOCs has increased from $<1 \mathrm{~s}^{-1}$ five years ago, to values approaching that of the biological OEC. Many groups have reported molecular water oxidation catalysts based on organic ligands since $2010^{[9]}$ and a few are briefly mentioned here. Some notable examples with Ir include $\left[\left(\mathrm{Cp}^{*}\right) \operatorname{Ir}\left(\text { pyr-CMe } \mathrm{CM}_{2} \mathrm{O}\right)\left(\mathrm{H}_{2} \mathrm{O}\right)\right]^{2+}$, where $\mathrm{Cp}^{*}=$ pentamethylcyclopentydienyl and pyr-CMe ${ }_{2} \mathrm{O}=2$-(2'-pyridyl)-2-propanolate, and $\left[\left(\mathrm{Cp}^{*}\right) \operatorname{Ir}\left(\mathrm{H}_{2} \mathrm{O}\right)_{3}\right]^{2+}$, the former being an authentic molecular WOC and the latter being prone to electrochemical ligand decomposition during water oxidation at an overpotential of 180 $\mathrm{mV}$, to an amorphous carbon containing $\mathrm{IrO}_{\mathrm{x}}$ film. ${ }^{[10]}$ In-situ monitoring of the film growth was achieved using an electrochemical quartz crystal nanobalance (EQCN). This decomposition has proved useful in the formation of thin $\mathrm{IrO}_{x}$ films. ${ }^{[11]}$ The related $\left[\left(\mathrm{Cp}^{*}\right) \operatorname{Ir}\left(\mathrm{L}_{2} \text { bpy }\right)\left(\mathrm{H}_{2} \mathrm{O}\right)\right]^{2+}$, where bpy $=2,2^{\prime}$ bipyridine and $\mathrm{L}=\mathrm{COOH}$ or $\mathrm{PO}_{3} \mathrm{H}_{2}$, was immobilized on an ITO electrode through the acid (oxy-anion) groups and reported to give stable current densities for water oxidation at an overpotential $=$ $760 \mathrm{mV}$ in $\mathrm{pH} 4$ buffer. In addition, $\left[(\mathrm{Cp} *) \operatorname{Ir}(\mathrm{bpy})\left(\mathrm{H}_{2} \mathrm{O}\right)\right]^{2+}$ was found to be a homogeneous $\mathrm{WOC}$ in $\mathrm{HNO}_{3}$ with $\mathrm{Ce}(\mathrm{IV})$ as the oxidant. No ligand oxidation was found and the lack of $\mathrm{IrO}_{\mathrm{x}}$ film formation was confirmed by EQCN. Unfortunately, the EQCN measurements were performed with the catalyst in solution with a gold electrode, thus these measurements do not fully match the catalytic conditions employed in the study (immobilized catalyst on ITO).

A few examples with cobalt are now discussed. When a similar ligand coordination environment is used for cobalt, $\left[\left(\mathrm{Cp} * \mathrm{Co}(\mathrm{bpy})\left(\mathrm{OH}_{2}\right)\right]^{2+}\right.$ acts as a precursor for $\mathrm{CoO}_{\mathrm{x}}$ through ligand oxidation during photochemical water oxidation with $\left[\mathrm{Ru}(\mathrm{bpy})_{3}\right]^{2+}$ as the photosensitizer and $\mathrm{S}_{2} \mathrm{O}_{8}{ }^{2-}$ as the sacrificial electron acceptor. ${ }^{[12]}$ The $\mathrm{Co}^{{ }^{1 I I}}{ }_{4} \mathrm{O}_{4}$ cubane, surrounded and stabilized by different ligands has enjoyed recent success as a molecular WOC, and has been touted as a cobalt analog of the manganese core in photosystem II. ${ }^{[9 e, 9 r, ~ 13] ~}\left[\mathrm{Co}^{\mathrm{IIII}}{ }_{4} \mathrm{O}_{4}(\mathrm{Ac})_{4}(\mathrm{pyr})_{4}\right]$, the first reported cubane WOC based on cobalt is an authentic molecular WOC, despite the presence of released $\mathrm{Co}^{2+}(\mathrm{aq})$ from the complex. This behavior contrasts that of ligated $\mathrm{Mn}_{4} \mathrm{O}_{4}$ cubanes, where the observed catalysis could be attributed to metal oxides. ${ }^{[14]}$ Another cubane, $\left[\mathrm{Co}_{4} \mathrm{II}_{4}(\mathrm{hmp})_{4}(\mu-\mathrm{OAc})_{2}\left(\mu_{2}-\mathrm{OAc}\right)_{2}\left(\mathrm{H}_{2} \mathrm{O}\right)_{2}\right]$, where $\mathrm{hmp}=2$-(hydroxymethylpyridine) was recently found to catalyze water oxidation with the $\left[\mathrm{Ru}(\mathrm{bpy})_{3}\right]^{2+} / \mathrm{S}_{2} \mathrm{O}_{8}{ }^{2-}$ from $\mathrm{pH} 5.8$ to 8 buffered solution with a maximum TON of 35 at $\mathrm{pH} 8$. No observable ligand oxidation or catalyst decomposition was found by dynamic light scattering, FT-IR (post-catalysis extraction) or UV-vis.

A lot of attention has been given to ruthenium-based molecular WOCs, given that the first one was reported over 30 years ago. ${ }^{[15]}$ $[\mathrm{Ru}(\mathrm{bda})$ (phthalazine) 2$]$, where bda $=2,2^{\prime}$-bipyridine-6,6'dicarboxylate was reported by Duan et al. to give TONs up to $\sim 5.5 \times 10^{4}$ with $\mathrm{Ce}(\mathrm{IV})$ as the oxidant in triflic acid. ${ }^{[16]}$ The authors note that catalyst deactivation occurs, but did not quantify the extent of deactivation, nor address what causes deactivation. Since no quantitative evidence of the stability of this complex was given, the number of catalytic cycles performed by the initial complex is not clear. ${ }^{[17]}$

Finally, copper-based WOCs have begun to appear in the field. Solutions from $\mathrm{pH} 11.8$ to 13.3 which contain simple copper salts and 2,2'-bpy were shown to be electrochemical WOCs at different electrode materials with a $750 \mathrm{mV}$ overpotential. ${ }^{[18]}$ The dominant species was found to be $\left(2,2^{\prime}-\mathrm{bpy}\right) \mathrm{Cu}(\mathrm{OH})_{2}$, which acts as a homogeneous WOC; no deposits on the electrode were found. The authors could not rule out that a colloidal material was the actual catalyst.

These important studies reinforce a key limitation of such catalysts: organic ligands are oxidatively unstable ${ }^{[14,}$ 19] with respect to $\mathrm{CO}_{2}$ and $\mathrm{H}_{2} \mathrm{O}$. They illustrate that in many, but not all, cases, WOC stability is not being addressed (not quantified under turnover conditions). ${ }^{[14]}$

\section{POM-based WOCs}

To circumvent the inherent oxidative and hydrolytic instability of the organic ligands in molecular water oxidation catalysts (WOCs), our group began to investigate polyoxometalate (POM)based catalysts in 2006. ${ }^{[20][21]}$ All known POM WOCs to date contain redox active d-electron transition-metal active sites where the key steps in the multi-electron (multi-PCET) process of water oxidation occur. POMs with $\mathrm{Ru}, \mathrm{Co}$ and $\mathrm{Ni}$ have been found to catalyze water oxidation by use of chemical oxidants, electrodes, or via photochemical means. ${ }^{[1 \mathrm{~h}, 13,21 \mathrm{~b}, 22]}$ In light of a recent review of the area of POM WOCs, ${ }^{[1 \mathrm{~h}]}$ we will only discuss a few POM WOCs here.

[\{Ru4 $\left.\left.\mathrm{O}_{4}(\mathrm{OH})_{2}\left(\mathrm{H}_{2} \mathrm{O}\right)_{4}\right\}\left(\gamma-\mathrm{SiW}_{10} \mathrm{O}_{36}\right)_{2}\right]^{10-}$ (“Ru4POM"): the first POM-based molecular water oxidation catalyst 
Our investigations of POM-based WOCs started with the diruthenium substituted $\gamma$-Keggin $\mathrm{POM}, \quad\left[\mathrm{Ru}^{\mathrm{III}}{ }_{2}(\mathrm{OH})_{2}(\gamma\right.$ $\left.\left.\mathrm{SiW}_{10} \mathrm{O}_{36}\right)\right]^{4-}\left(\mathrm{Ru}_{2} \mathrm{POM}\right){ }^{[21 a]}$ This complex showed a high catalytic activity in water oxidation but was hydrolytically unstable. During our attempts to understand the speciation of this complex, we isolated the dimer of $\mathrm{Ru}_{2} \mathrm{POM}, \quad\left[\left\{\mathrm{Ru}_{4} \mathrm{O}_{4}(\mathrm{OH})_{2}\left(\mathrm{H}_{2} \mathrm{O}\right)_{4}\right\}(\gamma-\right.$ $\left.\left.\mathrm{SiW}_{10} \mathrm{O}_{36}\right)_{2}\right]^{10-}\left(\mathrm{Ru}_{4} \mathrm{POM}\right)$ and discovered its high catalytic activity and stability in water oxidation by $\left[\mathrm{Ru}(\mathrm{bpy})_{3}\right]^{3+}$ at neutral $\mathrm{pH} \cdot{ }^{[21 b}$, 22b] At the same time, Sartorel et al. reported the synthesis of $\mathrm{Ru}_{4} \mathrm{POM}$ by a different procedure and showed its catalytic activity in water oxidation by $\mathrm{Ce}(\mathrm{IV})$ under highly acidic conditions. ${ }^{[22 \mathrm{a}]}$ Later this complex was used as a catalyst in a homogeneous visible-light-driven $\left[\mathrm{Ru}(\mathrm{bpy})_{3}\right]^{2+} / \mathrm{S}_{2} \mathrm{O}_{8}{ }^{2-}$ water oxidation system. ${ }^{[22 \mathrm{c}]}$ This or closely related visible-light-driven systems are now in common use to evaluate WOC activities. The $\mathrm{Ru}_{4} \mathrm{POM}$ has been successfully immobilized on different electrode surfaces for electrocatalytic water oxidation. ${ }^{[23]}$ Based on thermodynamic analysis, computational and new electrochemical studies of $\mathrm{Ru}_{4} \mathrm{POM}$, we identified that the intermediate, in which all $\mathrm{Ru}$ atoms are in oxidation state $\mathrm{V}$, is the dominant species forming $\mathrm{O}_{2}{ }^{[22 \mathrm{~b}, 22 \mathrm{~d}, 22 \mathrm{~h}, 24]}$ There is no indication of $\mathrm{Ru}_{4} \mathrm{POM}$ decomposition in the range of $\mathrm{pH}$ between 2 and 12..$^{[24 \mathrm{~b}]}$ The WOC chemistry of $\mathrm{Ru}_{4} \mathrm{POM}$ has been reviewed in several recent publications ${ }^{[1 \mathrm{~h}, 13,25]}$ and therefore further details are not discussed here.

\section{$\left[\mathrm{Co}_{4}\left(\mathrm{H}_{2} \mathrm{O}\right)_{2}\left(\mathrm{PW}_{9} \mathrm{O}_{34}\right)_{2}\right]^{10-}$ ("Co4 $\mathrm{POM}$ ") is a molecular water oxidation catalyst}

The POM water oxidation catalyst $\mathrm{Co}_{4} \mathrm{POM}$ is a molecular WOC when used with the chemical oxidant $\left[\mathrm{Ru}(\mathrm{bpy})_{3}\right]^{3+}$, as initially

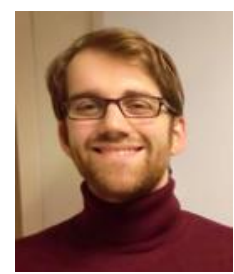

Jordan M. Sumliner obtained his B.S. in Chemistry from the State University of New York at New Paltz and began graduate studies at Emory University in 2010 under the advisement of Prof. Craig L. Hill. His graduate studies focus on immobilizing polyoxometalate water oxidation catalysts on electrodes.
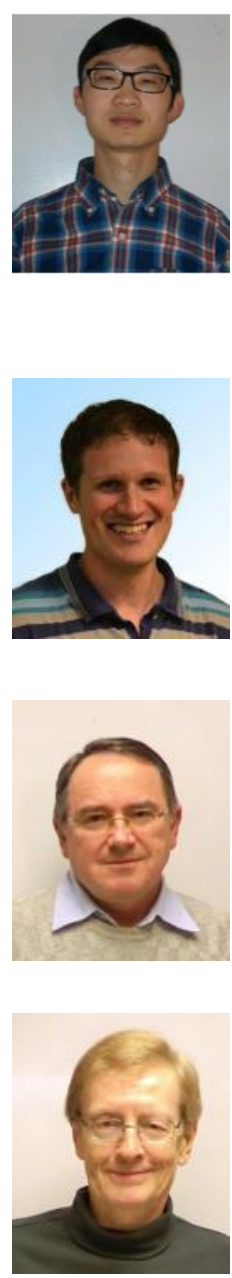

Hongjin Lv obtained his B.S. degree from Wuhan University in 2010. He is currently a Ph.D. candidate under the supervision of Prof. Craig L. Hill. His research interests focus on the development of novel transition-metal-substituted polyoxometalates for catalysis and solar energy conversion.
John Fielden obtained his MSci in Chemistry from the University of Bristol (2000) and Ph.D from the University of Glasgow (2004), under the supervision of Prof. Leroy Cronin. He was appointed to a Lectureship at the University of East Anglia in September 2012, following postdoctoral positions with Prof. Dr. Paul Kögerler (Ames Laboratory), Dr. Benjamin Coe (University of Manchester), and a Marie Curie Fellowship in the laboratory of Prof. Hill. John's research interests focus on the photonic and photo-catalytic properties of polyoxometalates and their derivatives.

Yurii V. Geletii obtained his MSci and Ph.D. in chemical physics from Moscow Institute of Physics and Technology. He worked in the Institute of Problems of Chemical Physics of Russian Academy of Science (Chernogolovka, Russia) and in the Laboratory of Coordination Chemistry CNRS (Toulouse, France). Since 1999, he is a senior scientist at Emory University. His research interests are in kinetics, thermodynamics and reaction mechanisms of homogeneous catalytic reactions.

Craig L. Hill is currently the Goodrich C. White Professor of Chemistry at Emory University. His group works in catalysis, artificial photosynthesis, multifunctional nanostructures and the chemistry, materials science and biology of inorganic cluster species. He has been the recipient of many awards including 3 from the American Chemical Society. He is a Fellow of the AAAS, VICS, and as of 2013, the Academia Europaea. His H index is $\sim 68$. 
reported by our group ${ }^{[22 \mathrm{i}]}$ and later verified by others. ${ }^{[26]}$ Later, this WOC was used with the oxidant $\mathrm{ClO}^{-[22 \mathrm{~s}]}$ and in a photochemical system with $\left[\mathrm{Ru}(\mathrm{bpy})_{3}\right]^{2+} / \mathrm{S}_{2} \mathrm{O}_{8}{ }^{2-}$ and other ruthenium polypyridyl photosensitizers. ${ }^{[22 \mathrm{k}, 27]}$ However, a limit of its use as a molecular WOC was revealed through careful studies by Stracke and Finke. ${ }^{[28]}$ This particular POM has been the focus of intense study over the past 3 years, ${ }^{[22 s,}{ }^{26,28-29]}$ as it was the fastest reported POM WOC based on earth-abundant elements (Co, W, P and O) at the time. ${ }^{[22 i]}$ Since d-electron metal oxides/polyhydroxides themselves can catalyze water oxidation, it is important to account for any amount of the hydrated metal cations (precursors to catalysts) that may exist in solution along with the POM. ${ }^{[27 a]}$ During the past year we again reported, and importantly reconfirmed, that $\mathrm{CO}_{4} \mathrm{POM}$ is an authentic POM WOC, with both $\left[\mathrm{Ru}(\mathrm{bpy})_{3}\right]^{3+}$ and with $\left[\mathrm{Ru}(\mathrm{bpy})_{3}\right]^{2+} / \mathrm{S}_{2} \mathrm{O}_{8}{ }^{2-}$ systems, despite the fact that $\mathrm{Co}^{2+}(\mathrm{aq})$ is present in solution. ${ }^{[27 a]}$ To do this, several experiments in addition to the seven in the original (Science, 2010) paper that addressed the nature of the actual catalytically active species, were conducted. Some of these experiments should have applicability to homogeneous WOC systems in general. One new line of experimentation was to show that the catalytic activity of twice the amount of $\mathrm{Co}^{2+}(\mathrm{aq})$ released upon extended aging and that of an equal amount of $\mathrm{CoO}_{\mathrm{x}}$, was far lower than the activity of the $\mathrm{Co} 4 \mathrm{POM}$ itself. A second experiment was demonstrating that when twice the amount of $\mathrm{Co}^{2+}(\mathrm{aq})$ detected (Table 1) was introduced to the catalytic system, no appreciable effect on the $\mathrm{O}_{2}$ yield was observed (Figure 1).

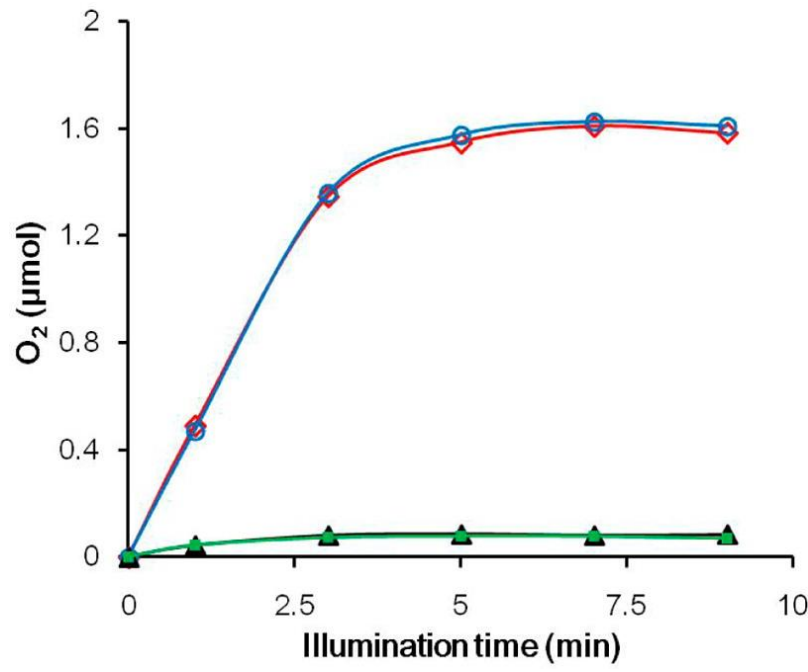

Figure 1. Kinetics of light-driven catalytic $\mathrm{O}_{2}$ evolution from water catalyzed by $\mathrm{Co}_{4} \mathrm{POM}$ and $\mathrm{Co}\left(\mathrm{NO}_{3}\right)_{2}$. Conditions: $455 \mathrm{~nm}$ light emitting diode $(17 \mathrm{~mW}$, beam diameter $\sim 0.5 \mathrm{~cm}), 5.0 \mathrm{mM} \mathrm{Na} \mathrm{S}_{2} \mathrm{O}_{8}, 1.0 \mathrm{mM}$ $\left[\mathrm{Ru}(\mathrm{bpy})_{3}\right] \mathrm{Cl}_{2}, 2.0 \mu \mathrm{M} \mathrm{Co}_{4} \mathrm{POM}$ (blue), $2.0 \mu \mathrm{M} \mathrm{Co} \mathrm{Co}_{4} \mathrm{POM}+0.15 \mu \mathrm{M}$ $\mathrm{Co}\left(\mathrm{NO}_{3}\right)_{2}$ (red), $0.15 \mu \mathrm{M} \mathrm{Co}\left(\mathrm{NO}_{3}\right)_{2}$ (black) all in $120 \mathrm{mM}$ sodium borate buffer, and $0.15 \mu \mathrm{M} \mathrm{Co}\left(\mathrm{NO}_{3}\right)_{2}$ (green) in $80 \mathrm{mM}$ sodium borate buffer. Initial $\mathrm{pH}=8.0$, total volume $2.0 \mathrm{~mL}$. Reproduced with permission from reference ${ }^{[27 a]}$. Copyright 2013 American Chemical Society

In addition to reporting the kinetics of oxidant consumption and $\mathrm{O}_{2}$ yields with $\mathrm{Co}^{2+}(\mathrm{aq})$ and $\mathrm{CoO}_{x}$ catalysts, we used a new POM extraction method, ${ }^{[27 a]}$ based on earlier work, ${ }^{[30]}$ which quantitatively removes $\mathrm{Co}_{4} \mathrm{POM}$ from the aqueous layer and transports it to an organic solvent (typically toluene) layer. The extraction leaves all other components in the system (essentially all the $\mathrm{Co}^{2+}$ and insoluble cobalt hydroxides / oxides) in the aqueous layer. This enabled us to measure the catalytic activity of the remaining species formed prior to, during or after catalytic water oxidation. The result of extraction of $\mathrm{Co}_{4} \mathrm{POM}$ from a pH 8.080 $\mathrm{mM}$ sodium borate buffer solution containing $5.0 \mathrm{mM} \mathrm{Na}_{2} \mathrm{~S}_{2} \mathrm{O}_{8}$ and $1.0 \mathrm{mM} \mathrm{Ru}(\mathrm{bpy})_{3} \mathrm{Cl}_{2}$ is dramatic: the $\mathrm{O}_{2}$ yield is negligible post extraction. If $\mathrm{Co}_{4} \mathrm{POM}$ is added back to the same solution, the $\mathrm{O}_{2}$ yield matches, within experimental error, that from an unmodified solution. The POM extraction technique will aid other researchers studying POM WOCs to distinguish them from other possible species that might be simultaneously present and catalytically active.

\section{When $\mathrm{CO}_{4} \mathrm{POM}$ and a related $\mathrm{POM}$ are not molecular water oxidation catalysts}

In contrast, $\mathrm{Co}_{4} \mathrm{POM}$ and a related $\mathrm{POM}$ $\left[\mathrm{Co}_{9}\left(\mathrm{H}_{2} \mathrm{O}\right)_{6}(\mathrm{OH})_{3}\left(\mathrm{HPO}_{4}\right)_{2}\left(\mathrm{PW}_{9} \mathrm{O}_{34}\right)_{3}\right]^{16-}, \mathrm{Co}_{9} \mathrm{POM}$, are not stable when used in solution as electrochemical water oxidation catalysts. This behavior establishes an important limit on the use of multicobalt POM WOCs. Not only is $\mathrm{Co}^{2+}(\mathrm{aq})$ released from the POMs, but the observed catalytic water oxidation activity in the system is the result of this released $\mathrm{Co}^{2+}(\mathrm{aq})$. When $\left[\mathrm{Co}_{4} \mathrm{POM}\right]=0.5 \mathrm{mM}$ at an overpotential $=580 \mathrm{mV}$ and when $\left[\mathrm{Co}_{9} \mathrm{POM}\right]=1.0 \mathrm{mM}$ at an overpotential $\approx 600 \mathrm{mV}$, the amount of $\mathrm{Co}^{2+}(\mathrm{aq})$ released during electrolysis is responsible for forming the actual catalyst $\left(\mathrm{CoO}_{\mathrm{x}}\right)$. When $\left[\mathrm{Co}_{4} \mathrm{POM}\right]=2.5 \mu \mathrm{M}$, the electrocatalytic activity of the POM at overpotential $\geq 600 \mathrm{mV}$ is indistinguishable from that of the observed amount of $\mathrm{Co}^{2+}(\mathrm{aq})$ released from the POM during the course of the experiment. While these studies define limits of stability and use of homogeneous water oxidation catalysis by multi-cobalt POMs, they do not detract from the overwhelming evidence that these POMs are molecular WOCs when used with chemical oxidants. That is, the exact conditions where the POMs serve as catalysts or as precursors to metal oxides are important when comparing them. These same issues pertain to all homogeneous WOCs, including those addressed above with organic ligands.

\section{Towards a better understanding of the complex equilibria associated with $\mathrm{CO}_{4} \mathrm{POM}$}

So far, studies on this POM have focused on how buffer, $\mathrm{pH}$, concentration and type of oxidant used control the catalytic activity in the system and the catalyst identity under different sets of conditions. Our group found that both the catalytic activity and stability of $\mathrm{Co}_{4} \mathrm{POM}$ strongly depend on $\mathrm{pH}$ and buffer identity. For example, the amount of $\mathrm{Co}^{2+}(\mathrm{aq})$ released from the parent POM after extended aging depends on the identity of the buffer (Table 1) and is one factor that describes the stability of the parent POM. It is likely that related POM WOCs, such as Co9POM would show a similar buffer dependence, but no studies have addressed this to date.

Table 1. Amount of $\mathrm{Co}^{2+}(\mathrm{aq})$ detected upon aging $\mathrm{Co}_{4} \mathrm{POM}$ in various buffers.

\begin{tabular}{ll}
\hline Buffer & $\mathrm{Co}^{2+}(\mathrm{aq})$ detected $(\mu \mathrm{M})^{[\mathrm{a}]}$ \\
\hline sodium phosphate & $0.44 \pm 0.02$ \\
sodium borate & $0.07 \pm 0.01$ \\
\hline
\end{tabular}

[a] $2.0 \mu \mathrm{M}$ of $\mathrm{Co}_{4} \mathrm{POM}$ was aged in $80 \mathrm{mM}$ of $\mathrm{pH} 8.0$ buffer for 3 hours The POM was extracted, and then the amount of $\mathrm{Co}^{2+}(\mathrm{aq})$ remaining in the buffered water was quantified by inductively coupled plasma mass spectrometry. 
However, it would be more helpful to understand the mechanism by which these POM WOCs equilibrate, so that one could rationally design new POM WOCs that are more stable to loss of the d-electron metal centers (or have equilibria where the metal is more stable in the POM rather than metal hydroxide/oxide). Recall that POMs themselves constitute dynamic systems and once in solution will equilibrate as governed by the law of mass action. This means, in the case of $\mathrm{Co}_{4} \mathrm{POM}$, its equilibrium concentration is strongly dependent on $\left[\mathrm{H}^{+}\right]$, $\left[\mathrm{WO}_{4}{ }^{2-}\right]$, $\left[\mathrm{HPO}_{4}{ }^{2-}\right]$ and $\left[\mathrm{Co}^{2+}\right]$ (eq. 3 ) and its formation from these components and that of related POMs is extremely dependent on the ratio of $\mathrm{Co}: \mathrm{X}: \mathrm{W}$, where $\mathrm{X}=\mathrm{POM}$ heteroatom. ${ }^{[31]}$

$$
\begin{gathered}
4 \mathrm{Co}^{2+}+18 \mathrm{WO}_{4}^{2-}+2 \mathrm{HPO}_{4}^{2-}+22 \mathrm{H}^{+} \rightleftharpoons \\
{\left[\mathrm{Co}_{4}\left(\mathrm{H}_{2} \mathrm{O}\right)_{2}\left(\mathrm{PW}_{9} \mathrm{O}_{34}\right)_{2}\right]^{10-}+10 \mathrm{H}_{2} \mathrm{O}}
\end{gathered}
$$

Likewise, slight variation in these concentrations, for example if the POM is placed in a buffer, acts as a driving force to partially decompose the POM. Indeed, Stracke and Finke noted that no observable (quantifiable) change in the UV-vis spectrum of 500 $\mu \mathrm{M} \mathrm{Co}_{4} \mathrm{POM}$ in $0.1 \mathrm{M} \mathrm{LiClO}_{4}$ occurs over a three-hour period. In marked contrast, Stracke and Finke noted the slow loss of Co4POM due to the release of $\mathrm{Co}^{2+}(\mathrm{aq})$ in buffer solutions at $\mathrm{pH} \mathrm{8.0,}{ }^{[28]}$ which we confirmed and showed occurs up to $\mathrm{pH} 10.0 .{ }^{[27 \mathrm{a}]}$ Our group found that this decomposition process is accelerated in sodium phosphate buffer, which may be the result of the formation of insoluble $\mathrm{Co}_{3}\left(\mathrm{PO}_{4}\right)_{2}$, which has a $\mathrm{K}_{\mathrm{sp}}=2.05 \times 10^{-35}$. ${ }^{[32]}$ To date, this species has not been isolated from a system containing $\mathrm{Co}_{4} \mathrm{POM}$ in sodium phosphate buffer.

Measurement of the equilibrium association constants for the metal, e.g. $\mathrm{Co}^{2+}(\mathrm{aq})$, in the POM ligands ( $\mathrm{K}_{\mathrm{eq}}$ values) is the logical first step towards understanding the complex equilibrium of these POMs. However, as correctly noted by Stracke and Finke, ${ }^{[28 a]}$ this has only been done so for non-WOC POMs. These numbers could support the formation of the proposed $\left[\mathrm{Co}_{3} \mathrm{Na}\left(\mathrm{H}_{2} \mathrm{O}\right)_{2}\left(\mathrm{PW}_{9} \mathrm{O}_{34}\right)_{2}\right]^{11-}$, suggested as a possible species that forms when $1.0 \mu \mathrm{M} \mathrm{C} \mathrm{C}_{4} \mathrm{POM}$ is electrolyzed at $\geq 1.3 \mathrm{~V}$ ( $\mathrm{vs} \mathrm{Ag} / \mathrm{AgCl}$ ) in $0.1 \mathrm{M} \mathrm{pH} 8.0$ sodium phosphate buffer. ${ }^{[28 \mathrm{~b}]}$ However, this route is unconfirmed, in part, because polytungstates equilibrate slowly, the exact species present are difficult to detect/quantify and the decomposition pathway

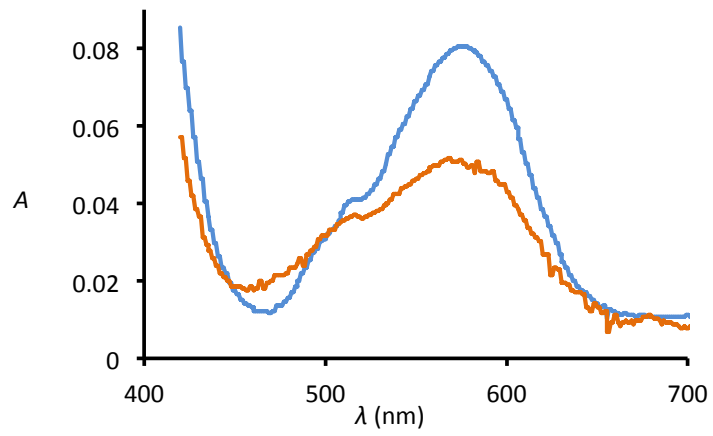

Figure 2. The UV-vis spectra of $0.5 \mathrm{mM} \mathrm{Co}{ }_{4} \mathrm{POM}$ in $80 \mathrm{mM} \mathrm{pH} 8.0$ sodium borate buffer before (blue) and after (orange) aging for 10 hours at $60{ }^{\circ} \mathrm{C}$.

is unknown. Therefore, during the course of a catalytic experiment (period of minutes) the POM never achieves true equilibrium. The only species that we have direct evidence for and can quantify are $\mathrm{Co} 4 \mathrm{POM}$ and $\mathrm{Co}^{2+}(\mathrm{aq})$. Under quiescent conditions in the presence of buffer, we observe a slow, $\mathrm{pH}$-dependent release of $\mathrm{Co}^{2+}(\mathrm{aq})$ over a three-hour period for this POM, again suggesting that equilibrium for this process favors the POM. Aging experiments at room temperature for up to 12 hours continue to show a slow loss of $\mathrm{Co}_{4} \mathrm{POM}$; even upon heating the system (solution) to $60{ }^{\circ} \mathrm{C}$ for 10 hours fails to drive the system to full equilibrium (Figure 2). At this time, we cannot not identify by UV-vis, all of the products that form after heating or aging the solutions for long periods of time (Figure 2), and therefore are unable to calculate equilibrium association constants, or $\mathrm{K}_{\mathrm{eq}} \cdot{ }^{[27 \mathrm{a}]}$ Developing a handle to identify the specific POM species present would greatly aid design of new POM WOCs.

\section{POM-catalyzed multi-electron reduction reactions}

Several features of natural photosynthesis are typically modelled in the reduction or fuel-forming unit as well the light absorptioncharge separation and water oxidation units in artificial photosynthetic systems. Reductive equivalents are generated by light irradiation coupled with redox cycles in Photosystems I and II. The promise of efficient and sustainable photocatalytic water splitting into $\mathrm{H}_{2}$ and $\mathrm{O}_{2}$ has inspired researchers to develop promising heterogeneous ${ }^{[91,}{ }^{33]}$ and homogeneous ${ }^{[33 \mathrm{~b},}{ }^{34]}$ photocatalysts for the reaction. Ideally, these photocatalysts would be coupled with WOCs in order to develop light-driven water splitting systems.

Photocatalysis based on dispersion of heterogeneous semiconductor particles continues to offer promise because these particles are frequently quite robust under strong light illumination, readily prepared and many are low cost. ${ }^{[33 \mathrm{~b}, 33 \mathrm{~d}, 35]}$ Nevertheless, it is important to control the chemical conversion processes at the molecular level and to easily study them both experimentally and computationally at this level in order to achieve highly efficient catalytic cycles like those in nature. ${ }^{[36]}$ There is a plethora of noblemetal-based catalysts ${ }^{[37]}$ and/or chromophores ${ }^{[34 c, 38]}$ whereas, systems based exclusively on earth-abundant elements continue to be few in number. ${ }^{[34 b, 39]}$ Since POMs are capable of accepting multiple electrons, their use as $\mathrm{H}_{2} \mathrm{O}$ and/or $\mathrm{CO}_{2}$ reduction catalysts is logical, however there are few examples of noble-metal-free POM water reduction catalysts (WRCs).

\section{Reduced POMs as WRCs}

Reduced POMs ${ }^{[40]}$ typically generated by UV irradiation in the presence of organic substrates ${ }^{[41]}$ have long been known to slowly evolve $\mathrm{H}_{2}$ in acidic aqueous media. After early reports, ${ }^{[40,42]}$ and the demonstration by Darwent that $\operatorname{Pt}(0)$ could catalyze the reoxidation of reduced POMs, ${ }^{[41]}$ several studies on UV-lightinduced photooxidation of organic substrates catalyzed by various POMs with simultaneous $\mathrm{H}_{2}$ evolution catalyzed by $\mathrm{Pt}(0)$ were published. ${ }^{[6 a, 42-43]}$

None of these initial studies reported high rates of $\mathrm{H}_{2}$ evolution in the absence of $\operatorname{Pt}(0)$. One exception is POM-modified carbon electrodes that electrochemically reduce protons to $\mathrm{H}_{2}$ reported by Nadjo, Keita and coworkers in the mid 1980s and early 1990s. However, the actual catalyst in these systems was never fully identified ${ }^{[44]}$ and these systems do not utilize light. Clearly, the development of cheap, readily available, visible-light-response and abundant-metal-based systems as a substitute for noble metals is a 
general challenge in catalyzed multi-electron processes and a major goal in artificial photosynthesis. Recently, Artero, Proust and coworkers $^{[45]}$ developed a covalent-linked $\operatorname{Ir}(\mathrm{III})$-photosensitized POM complex, which shows very efficient photoreduction of a polyoxometalate in the presence of sacrificial electron donor upon visible light irradiation. Photocatalytic $\mathrm{H}_{2}$ production proceeds without obvious loss of activity for more than one week; however, a TON of only 41 is obtained after 7 days of irradiation. ${ }^{[14]}$

\section{A noble-metal-free POM-based WRC}

In an effort to develop hydrolytically stable, more efficient and noble-metal-free molecular water reduction catalysts (WRCs), our group started systemically evaluating the large experimental space defined by suitable families of POMs, and recently reported visible-light-driven hydrogen evolution from water catalyzed by a tetra-manganese-containing $\mathrm{POM}, \quad \mathrm{Na}_{10}\left[\mathrm{Mn}_{4}\left(\mathrm{H}_{2} \mathrm{O}\right)_{2}\left(\mathrm{VW}_{9} \mathrm{O}_{34}\right)_{2}\right]$ $\left(\mathrm{Mn}_{4} \mathrm{POM}\right) .{ }^{[46]}$ Steady-state and time-resolved fluorescence decay studies confirm the oxidative quenching of $\left[\mathrm{Ru}(\mathrm{bpy})_{3}\right]^{2+*}$ (the ${ }^{3}$ MLCT excited state) by $\mathrm{Mn}_{4} \mathrm{POM}$. The resulting reduced form of the catalyst reacts with water, confirmed by isotope labeling experiments, to generate $\mathrm{H}_{2}$. Under minimally optimized conditions, a TON of 42 was obtained after $5.5 \mathrm{~h}$ of irradiation. Although its present efficiency is higher than the $\operatorname{Ir}(\mathrm{III})$ photosensitized POM catalyst, ${ }^{[14]}$ it is still too low for practical use. The longer-term stability of $\mathrm{Mn}_{4} \mathrm{POM}$ was assessed by UV-vis under quiescent conditions for $21 \mathrm{~h}$, which found only a $1 \%$ decrease in absorbance due to the POM. FT-IR analysis of the catalyst isolated after an extended period of irradiation $(24 \mathrm{~h})$ confirmed that the POM is intact, although this is not a quantitative measure of its stability. Our group is currently targeting mono/multi-transition-metal-containing but noble-metal-free POM catalysts for the reduction of $\mathrm{H}_{2} \mathrm{O}$ and $\mathrm{CO}_{2}$ under either electrocatalytic and photochemical conditions. By carefully tailoring the electronic structures, more viable (fast, selective and stable) POM WRCs and $\mathrm{CO}_{2}$ reduction catalysts should be identified.

\section{Polyoxometalate WOC functionalized photoanodes}

Studies of polyoxometalate-based water oxidation photoanodes have so far been limited. These studies have focused on "triads" consisting of n-type semiconductor metal oxides $\left(\mathrm{TiO}_{2}, \mathrm{SnO}_{2}\right)$, ruthenium-based sensitizer dyes, and $\left[\left\{\mathrm{Ru}_{4} \mathrm{O}_{4}(\mathrm{OH})_{2}\left(\mathrm{H}_{2} \mathrm{O}\right)_{4}\right\}(\gamma-\right.$ $\left.\left.\mathrm{SiW}_{10} \mathrm{O}_{36}\right)_{2}\right]^{10-}\left(\mathrm{Ru}_{4} \mathrm{POM}\right)$ catalyst. ${ }^{[47]}$

These systems are essentially POM-containing analogs of other dye-sensitized water oxidation photoanodes published in the last five years ${ }^{[48]}$ and as such, their operating principle is similar to that of the dye-sensitized solar cell (DSSC) - electrons are injected from the sensitizers into the $\mathrm{TiO}_{2}$ conduction band (Scheme 1).

However, instead of regeneration by a redox mediator, the oxidized sensitizers take electrons from the catalyst, which in turn oxidizes water. In POM triad studies, $\mathrm{Ru}_{4} \mathrm{POM}$, despite its lower speed, has been the catalyst of choice for three reasons. Firstly, its strong UV-vis absorption provides a handle allowing straightforward quantification of its presence on the electrode surface. Secondly, it has a wider $\mathrm{pH}$ range of activity (and stability) in aqueous media than most POM WOCs reported thus far. Lastly, as discussed above, the triad system would subject multi-cobalt POMs to conditions that facilitate their decomposition (i.e. high electrochemical bias). However, a water insoluble salt of Co9POM does appear to be stable in a carbon paste anode. ${ }^{[22 \mathrm{v}]}$
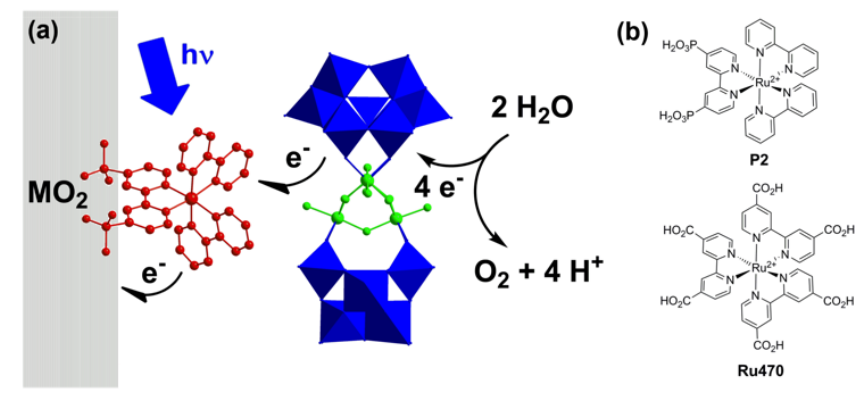

Scheme 1. (a) Principle operation of a triadic water oxidizing photoanode incorporating $\mathrm{Ru}_{4} \mathrm{POM}$. (b) Structures of the $\mathbf{P 2}$ and $\mathbf{R u 4 7 0}$ dyes which have been used in triads with $\mathrm{Ru}_{4} \mathrm{POM}$.

The first study of $\mathrm{Ru}_{4} \mathrm{POM}$ at a dye-sensitized electrode was performed by Bonchio, Scandola et al. ${ }^{[47 \mathrm{a}]}$ This nanosecond flash photolysis study on $\mathrm{TiO}_{2}-\left[\mathrm{Ru}(\mathrm{bpy})_{2}(\mathrm{dpbpy})\right]^{2+}(\mathbf{P 2})-\mathrm{Ru}_{4} \mathrm{POM}$, where dpbpy $=2,2$, 'bipyridine-4,4'-dicarboxylate, indicated that the bleach resulting from photooxidation of the dye recovered significantly faster in the presence of the catalyst, suggesting electron transfer to the oxidized dye. Subsequently, we investigated $\mathrm{Ru}_{4} \mathrm{POM}$ at $\mathrm{TiO}_{2}$ using the carboxylate binding dye $\mathrm{Ru} 470$, with fs to ns visible transient absorption spectroscopy which indicated accelerated bleach recovery on this faster timescale. ${ }^{[47 b]}$ Our most recent and comprehensive study returned to the phosphonate-binding $\mathbf{P 2}$ system, ${ }^{[47 \mathrm{c}]}$ due to its superior resistance to hydrolysis, and investigated $\mathrm{SnO}_{2}$ and $\mathrm{ZrO}_{2}$ in addition to $\mathrm{TiO}_{2}$. Importantly, ultrafast transient IR measurements confirmed that electrons were still injected into $\mathrm{TiO}_{2}$ in the presence of the catalyst, and visible transient measurements on the $\mathrm{ZrO}_{2}$ control (which cannot accept electrons from the $\mathbf{P 2}$ excited state) eliminated a dye-catalyst quenching phenomenon as the major source of the bleach recovery. Half-lifetimes for the

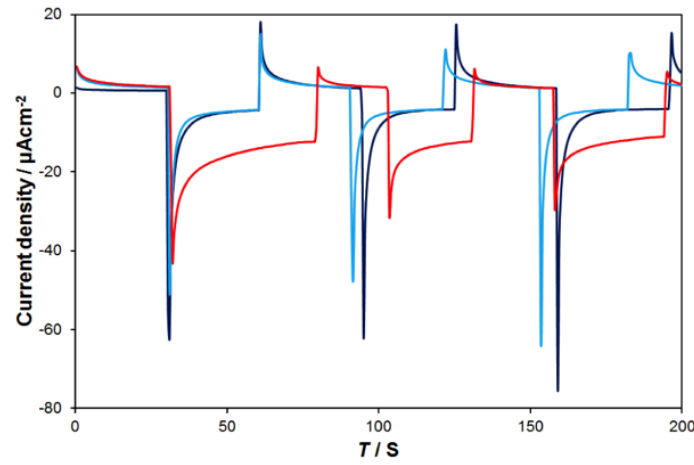

Figure 3. Photoelectrochemical measurements (chronoamperometry) of $\mathrm{TiO}_{2}-\mathbf{P 2}$ (dark blue), $\mathrm{TiO}_{2}-\mathbf{P 2}-\mathrm{Zn}_{4} \mathrm{POM}$ (light blue), and $\mathrm{TiO}_{2}-\mathbf{P 2}-\mathrm{Ru}_{4} \mathrm{POM}$ (red) films at an applied bias of $0 \mathrm{mV}$ vs $\mathrm{Ag} / \mathrm{AgCl}, \mathrm{pH}$ 5.8. Reproduced with permission from reference. ${ }^{[47 \mathrm{c}]}$ Copyright 2013 American Chemical Society

recovery of oxidized $\mathbf{P 2}$ of 127 ps (on $\left.\mathrm{TiO}_{2}\right)$ and 520 ps $\left(\mathrm{SnO}_{2}\right)$ were established: these are significantly faster than regeneration of Ru-polypyridyl dyes by I- in the DSSC, ${ }^{[49]}$ and around 6 orders of 
magnitude faster than those from $\mathrm{IrO}_{2}$ to related sensitizers. ${ }^{[50]}$ Furthermore, evidence was seen for the persistence of $\mathrm{TiO}_{2}\left(\mathrm{e}^{-}\right)-\mathbf{P 2}$ $\mathrm{Ru}_{4} \mathrm{POM}\left(\mathrm{h}^{+}\right)$excited states beyond $0.5 \mu$ s. In principle, this rapid electron transfer and long-lived charge-separated state is very encouraging for the use of these systems in light-driven water oxidation. Indeed, significant $(100 \%)$ photocurrent enhancements (Figure 3) are observed when $\mathrm{Ru}_{4} \mathrm{POM}$ is added to $\mathrm{TiO}_{2}-\mathbf{P 2}$ at $\mathrm{pH}$ 5.8 - such enhancements are not achieved with the inactive POM, $\left[\mathrm{Zn}_{4}\left(\mathrm{H}_{2} \mathrm{O}\right)_{2}\left(\mathrm{PW}_{9} \mathrm{O}_{34}\right)_{2}\right]^{10-}\left(\mathrm{Zn}_{4} \mathrm{POM}\right)$, or in the absence of water, suggesting oxidation of water was the source of the photocurrent. However, the quantum efficiency (ca. $0.2 \%$ ) is significantly lower than that for the related $\mathrm{IrO}_{2}$-based system described above, ${ }^{[48 \mathrm{a}]}$ and nearly two orders of magnitude lower than that recently achieved for triads based on a super-fast, Ru bipyridine dicarboxylic acid complex. ${ }^{[48 \mathrm{e}]}$ Given the favourable electron transfer dynamics described above, it appears that replacing $\mathrm{Ru}_{4} \mathrm{POM}$ with a faster POM WOC is the key to developing higher performance POMfunctionalized photoanodes.

We will shortly report in more detail on $\mathrm{O}_{2}$ evolution, and the stability of these triadic systems. Despite their apparent promise, however, they suffer from two important Achilles' heels when it comes to stability: oxidation of the dye, and desorption of both dye and catalyst. Both of these tend to become more severe in the $\mathrm{pH}>$ 7 range where POM catalysts are most active. While many steps may be taken to mitigate these problems, such as use of polymerized dyes, ${ }^{[51]}$ completely overcoming them is likely to require alternative, purely inorganic, light-absorbing supports. Importantly, no results obtained thus far indicate that POM WOC stability is the success limiting factor in the triadic systems.

\section{Conclusions}

The synthesis, X-ray structures, spectroscopic properties and catalytic activity of many polyoxometalate (POM) water oxidation catalysts (WOCs) and some water reduction catalysts (WRCs) have now been reported. On the reduction side, only a few examples of noble-metal-free POM water reduction catalyst exist, but there is vast potential for their continued development, including incorporation into photocathodes. POM WOC immobilization on a range of carbon-based and metal oxide supports has been achieved and the properties of these dyadic systems have been elucidated using various approaches and techniques. One limitation to viable triads is photosensitizer degradation and viable inorganic analogues are not yet available. However, POM WOCs, unlike coordination compounds, are carbon-free and thus thermodynamically stable with respect to oxidative degradation; they are thermally stable and also hydrolytic stable over wide $\mathrm{pH}$ ranges that vary with the POM ligand structure, the active-site d-electron metals, and solution parameters. One solution parameter that has impacted publications to date is the use of phosphate containing buffers. Phosphate should be avoided because it inhibits water oxidation and cobalt phosphate is thermodynamically more stable hydrolytically at neutral and basic $\mathrm{pH}$ values than the cobalt-containing POMs.

A central challenge, not just with POM WOCs, but essentially all molecular WOCs, is to establish the amount of different species present that are catalytically active for water oxidation under turnover conditions. Nearly all literature studies of homogeneous WOCs note decomposition of the WOC during turnover, and sometimes note that metal oxide (typically $\mathrm{RuO}_{2}$ from oxidative followed by hydrolytic decomposition of Ru-based coordination compound WOCs) is a likely decomposition product of the initial catalyst that forms during turnover. These studies, however, do not quantify the amount of hydrated metal cation that forms from the initial molecular WOC during turnover nor the amount of metal oxide WOC that forms from the metal cation during catalysis. Therefore, the amount of water oxidation that arises from transient hydrated metal cations or subsequently forming metal oxide particles is unknown. Additional detailed studies on these decomposition pathways for all WOCs could facilitate development of more robust catalysts.

Since nearly all molecular water and $\mathrm{CO}_{2}$ reduction catalysts are ultimately susceptible to hydrolytic degradation, the development of POM catalysts for these reductions is of considerable interest: POMs can be formulated to be thermodynamically stable to hydrolysis over wide $\mathrm{pH}$ ranges in aqueous media. Thus far the rates of these reductions are very slow. However, many parameters have yet to be examined and optimized. One must note in the parallel study and development of POM WOCs in our laboratory over the last 5 years that the water oxidation $/ \mathrm{O}_{2}$ evolution rates of these systems have increased 10,000-fold or more through systematic and targeted variation of the POM compositions and structures. The same situation may apply for the development and optimization of POM reduction catalysts.

Finally, it is clear from the early research thus far that POMs can function as effective WOCs in triadic systems. The lifetimes of these systems under operating (turnover) conditions is not dictated by POM decomposition but rather by dye (photosensitizer) decomposition and hydrolytic displacement of the dye off the semiconductor metal oxide electrode surface.

\section{Acknowledgments}

We thank the U. S. Department of Energy, Office of Basic Energy Sciences, Solar Photochemistry Program (DE-FG02-07ER15906) for support of the research on WOCs, triads, and the U.S. NSF (Grant Number CHE0911610) for research on the POM reduction catalysts.

[1] a) N. S. Lewis, D. G. Nocera, Proc. Natl. Acad. Sci. 2006, 103(43), 15729-15735; b) S. Shafiee, E. Topal, Energy Policy 2009, 37, 181 189 ; c) L. Hammarstrom, S. Hammes-Schiffer, Acc. Chem. Res 2009, 42, 1859-1860; d) J. Barber, Chem. Soc. Rev. 2009, 38, 185196; e) E. S. Andreiadis, M. Chavarot-Kerlidou, M. Fontecave, V. Artero, Photochem. Photobiol. 2011, 1-19; f) W. Song, Z. Chen, M. K. Brennaman, J. J. Concepcion, A. O. T. Patrocinio, N. Y. M. Iha, T. J. Meyer, Pure Appl. Chem. 2011, 83, 749-768; g) A. B. Lovins, Rocky_Mountain_Institute, Defossilizing Fuels, Chapter 1, Fig 1-3, "Fossil fuels: global production, 1800-2200", Chelsea Green Publishing Co, White River Junction, VT, 2011; h) H. Lv, Y. V. Geletii, C. Zhao, J. W. Vickers, G. Zhu, Z. Luo, J. Song, T. Lian, D. G. Musaev, C. L. Hill, Chem. Soc. Rev. 2012, 41, 7572-7589; i) T. Faunce, S. Styring, M. R. Wasielewski, G. W. Brudvig, A. W Rutherford, J. Messinger, A. F. Lee, C. L. Hill, H. deGroot, M Fontecave, D. R. MacFarlane, B. Hankamer, D. G. Nocera, D. M Tiede, H. Dau, W. Hillier, L. Wang, R. Amal, Energy Environ. Sci. 2013, 6, 1074-1076; j) P. D. Frischmann, K. Mahata, F. Würthner, Chem. Soc. Rev. 2013, 42, 1847-1870.

[2] C. G. a. daSilva, Energy 2010, 35, 1312-13156.

[3] a) R. I. Cukier, D. G. Nocera, Annu. Rev. Phys. Chem. 1998, 49, 337 369; b) S. Hammes-Schiffer, Chem. Rev. 2010, 110, 6937-6938; c) D. R. Weinberg, C. J. Gagliardi, J. F. Hull, C. F. Murphy, C. A. Kent, B. 
C. Westlake, A. Paul, D. H. Ess, D. Granville, McCafferty, T. J. Meyer, Chem. Rev. 2012, 112, 4016-4093.

[4] a) M. T. Pope, A. Müller, Angew. Chem. 1991, 103, 56-70; b) C. L. Hill, Chem. Rev. 1998, 98, 1-2; cJ. J. Borrás-Almenar, E. Coronado, A. Müller, M. T. Pope, Polyoxometalate Molecular Science. Proceedings of the NATO Advanced Study Institute, Tenerife, Spain from 25 August to 4 September 2001, Vol. 98, Kluwer Academic Publishers, Dordrecht, 2003; d) D.-L. Long, R. Tsunashima, L. Cronin, Angew. Chem. Int. Ed. 2010, 49, 1736-1758; e) L. Cronin, A. Muller, Chem. Soc. Rev. 2012, 41, 7333-7334.

[5] a) C. L. Hill, C. M. Prosser-McCartha, Coord. Chem. Rev. 1995, 143 407-455; b) R. Neumann, Prog. Inorg. Chem. 1998, 47, 317-370; c C. L. Hill, J. Mol. Catal. A: Chem. 2007, 262, 2-6.

[6] a) C. L. Hill, D. A. Bouchard, J. Am. Chem. Soc. 1985, 107, 5148 5157; b) C. L. Hill, R. B. Brown, Jr., J. Am. Chem. Soc. 1986, 108 , 536-538; c) R. F. Renneke, M. Kadkhodayan, M. Pasquali, C. L. Hill, J. Am. Chem. Soc. 1991, 113, 8357-8367; d) D. Sattari, C. L. Hill, J. Am. Chem. Soc. 1993, 115, 4649-4657; e) M. K. Harrup, C. L. Hill, Inorg. Chem. 1994, 33, 5448-5455; f) C. L. Hill, Synlett 1995, 127 132; g) R. D. Gall, C. L. Hill, J. E. Walker, Chem. Mater. 1996, 8 2523-2527; h) H. Zeng, G. R. Newkome, C. L. Hill, Angew. Chem. Int. Ed. 2000, 39, 1771-1774.

[7] a) T. Okuhara, N. Mizuno, M. Misono, Adv. Catal. 1996, 41, 113 252; b) N. Mizuno, M. Misono, Chem. Rev. 1998, 98, 199-218.

[8] a) C. Zhao, Z. Huang, W. Rodríguez-Córdoba, C. S. Kambara, K. P. O’Halloran, K. I. Hardcastle, D. G. Musaev, T. Lian, C. L. Hill, J. Am. Chem. Soc. 2011, 133, 20134-20137; b) C. Zhao, W. RodríguezCórdoba, A. L. Kaledin, Y. Yang, Y. V. Geletii, T. Lian, D. G. Musaev, C. L. Hill, Inorg. Chem. 2013, ASAP; c) C. Zhao, C. S Kambara, Y. Yang, A. L. Kaledin, D. G. Musaev, T. Lian, C. L. Hill, Inorg. Chem. 2013, 52, 671-678.

[9] a) Y. Xu, A. Fischer, L. Duan, L. Tong, E. Gabrielsson, B. Åkermark, L. Sun, Angew. Chem. Int. Ed. 2010, 49, 8934-8937; b) L. Duan, Y. $\mathrm{Xu}, \mathrm{M}$. Gorlov, L. Tong, S. Andersson, L. Sun, Chem. Eur. J. 2010 16, 4659-4668; c) W. C. Ellis, N. D. McDaniel, S. Bernhard, T. J. Collins, J. Am. Chem. Soc. 2010, 132, 10990-10991; d) D. J. Wasylenko, C. Ganesamoorthy, B. D. Koivisto, M. A. Henderson, C P. Berlinguette, Inorg. Chem. 2010, 49, 2202-2209; e) N. S. McCool, D. M. Robinson, J. E. Sheats, G. C. Dismukes, J. Am. Chem. Soc 2011, 133, 11446-11449; f) Z. Chen, J. J. Concepcion, T. J. Meyer, Dalton Trans. 2011, 40, 3789-3792; g) J. L. Fillol, Z. Codolà, I Garcia-Bosch, L. Gómez, J. J. Pla, M. Costas, Nature Chem. 2011, 3 807-813; h) L. Duan, Y. Xu, L. Tong, L. Sun, ChemSusChem 2011 4, 238-244; i) L. Bernet, R. Lalrempuia, W. Ghattas, H. MuellerBunz, L. Vigara, A. Llobet, M. Albrecht, Chem. Commun. 2011, 47, 8058-8060; j) S. Roeser, P. Fàrrs, F. Bozoglian, M. MartínezBelmonte, J. Benet-Buchholz, A. Llobet, ChemSusChem 2011, 4 197-207; k) L. Tong, Y. Wang, L. Duan, Y. Xu, X. Cheng, A. Fischer, M. S. G. Ahlquist, L. Sun, Inorg. Chem. 2012, 51, 33883398; 1) P. Du, R. Eisenberg, Energy Environ. Sci. 2012, 5, 6012 6021; m) L. Duan, F. Bozoglian, S. Mandal, B. Stewart, T. Privalov, A. Llobet, L. Sun, Nature Chem. 2012, 4, 418-423; n) J. An, L. Duana, L. Sun, Faraday Discuss. 2012, 155, 267-275; o) S. Pintado, S. Goberna-Ferrón, E. C. Escudero-Adán, J. R. Galán-Mascarós, J. Am. Chem. Soc. 2013, 135, 13270-13273; p) A. Singh, L. Spiccia Coord. Chem. Rev. 2013, 257, 2607-2622; q) T. Nakazono, A. R. Parent, K. Sakai, Chem. Commun. 2013, 49, 6325-6327; r) G. LaGanga, F. Puntoriero, S. Campagna, I. Bazzan, S. Berardi, M. Bonchio, A. Sartorel, M. Natali, F. Scandola, Faraday Discuss. 2012 155, 177-190; s) K. S. Joya, N. K. Subbaiyan, F. D'Souza, H. J. M. d. Groot, Angew. Chem. Int. Ed. 2012, 51, 9601-9605; t) R. Cao, W. Lai, P. Du, Energy Environ. Sci. 2012, 5, 8134-8157; u) F. Li, Y. Jiang, B. Zhang, F. Huang, Y. Gao, L. Sun, Angew. Chem. Int. Ed. 2012, 51, 2417-2420; v) M.-T. Zhang, Z. Chen, P. Kang, T. J. Meyer, J. Amer. Chem. Soc. 2013, 135, 2048-2051; w) L. Wang, L. Duan, L. Tong, L. Sun, J. Catal. 2013, 306, 129-132; x) J. J. Concepcion, J. W. Jurss, M. R. Norris, Z. Chen, J. L. Templeton, T. J. Meyer, Inorg. Chem. 2010, 49, 1277-1279; y) A. Lewandowska-Andralojc, D. E Polyansky, R. Zong, R. P. Thummel, E. Fujita, Phys. Chem. Chem. Phys. 2013, 15, 14058-14068; z) T. Wada, J. T. Muckerman, E. Fujita, K. Tanaka, Dalton Trans. 2011, 40, 2225-2233; aa) Y. M. Badiei, D. E. Polyansky, J. T. Muckerman, D. J. Szalda, R. Haberdar, R. Zong, R. P. Thummel, E. Fujita, Inorg. Chem. 2013, 52, 8845-
8850; ab) T. Zhang, C. Wang, S. Liu, J.-L. Wang, W. Lin, J. Am Chem. Soc. 2013

[10] N. D. Schley, J. D. Blakemore, N. K. Subbaiyan, C. D. Incarvito, F D’Souza, R. H. Crabtree, G. W. Brudvig, J. Am. Chem. Soc. 2011 133, 10473-10481.

[11] M. N. Kushner-Lenhoff, J. D. Blakemore, N. D. Schley, R. H Crabtree, G. W. Brudvig, Dalton Trans. 2013, 42, 3617-3622.

[12] D. Hong, J. Jung, J. Park, Y. Yamada, T. Suenobu, Y.-M. Lee, W Nam, S. Fukuzumi, Energy Environ. Sci. 2012, 5, 7606-7616.

[13] A. Sartorel, M. Bonchio, S. Campagna, F. Scandola, Chem. Soc. Rev. 2013, 42, 2262-2280.

[14] V. Artero, M. Fontecave, Chem. Soc. Rev. 2012, 42, 2338-2356.

[15] S. W. Gersten, G. J. Samuels, T. J. Meyer, J. Am. Chem. Soc. 1982 104, 4029-4030.

[16] L. Duan, C. M. Araujo, M. S. G. Ahlquist, L. Sun, Proc. Natl. Acad. Sci. 2012, 109, 15584-15588.

[17] The TONs calculated by Duan et al. were obtained by dividing the final oxygen yield with the initial concentration of the catalyst.

[18] S. M. Barnett, K. I. Goldberg, J. M. Mayer, Nature Chem. 2012, 4 , 498-502.

[19] B. Limburg, E. Bouwman, S. Bonnet, Coord. Chem. Rev. 2012, 256 , 1451-1467.

[20] The POM ligands themselves are oxidatively stable since they contain transition metals in their highest oxidation state. Since POMs are themselves dynamic systems, they are not expected to be fully intact in solution. That is, they should approach an equilibrium with their base components.

[21] a) D. Quiñonero, Y. Wang, K. Morokuma, L. A. Khavrutskii, B. Botar, Y. V. Geletii, C. L. Hill, D. G. Musaev, J. Phys. Chem. 2006 110, 170-173; b) Y. V. Geletii, B. Botar, P. Kögerler, D. A Hillesheim, D. G. Musaev, C. L. Hill, Angew. Chem. Int. Ed. 2008 47, 3896-3899.

[22] a) A. Sartorel, M. Carraro, G. Scorrano, R. D. Zorzi, S. Geremia, N D. McDaniel, S. Bernhard, M. Bonchio, J. Am. Chem. Soc. 2008 130, 5006-5007; b) Y. V. Geletii, C. Besson, Y. Hou, Q. Yin, D. G. Musaev, D. Quinonero, R. Cao, K. I. Hardcastle, A. Proust, P. Kögerler, C. L. Hill, J. Am. Chem. Soc. 2009, 131, 17360-17370; c) Y. V. Geletii, Z. Huang, Y. Hou, D. G. Musaev, T. Lian, C. L. Hill, J. Am. Chem. Soc. 2009, 131, 7522-7523; d) A. E. Kuznetsov, Y. V. Geletii, C. L. Hill, K. Morokuma, D. G. Musaev, J. Am. Chem. Soc. 2009, 131, 6844-6854; e) A. Sartorel, P. Miro, E. Salvadori, S Romain, M. Carraro, G. Scorrano, M. D. Valentin, A. Llobet, C. Bo, M. Bonchio, J. Am. Chem. Soc. 2009, 131, 16051-16053; f) R. Cao H. Ma, Y. V. Geletii, K. I. Hardcastle, C. L. Hill, Inorg. Chem. 2009, 48, 5596-5598; g) C. Besson, Z. Huang, Y. V. Geletii, S. Lense, K. I. Hardcastle, D. G. Musaev, T. Lian, A. Proust, C. L. Hill, Chem. Commun. 2010, 2784-2786; h) D. Quiñonero, A. L. Kaledin, A. E Kuznetsov, Y. V. Geletii, C. Besson, C. L. Hill, D. G. Musaev, J. Phys. Chem. A 2010, 114, 535-542; i) Q. Yin, J. M. Tan, C. Besson, Y. V. Geletii, D. G. Musaev, A. E. Kuznetsov, Z. Luo, K. I Hardcastle, C. L. Hill, Science 2010, 328, 342-345; j) Y. V. Geletii, Q. Yin, Y. Hou, Z. Huang, H. Ma, J. Song, C. Besson, Z. Luo, R. Cao, K. P. O'Halloran, G. Zhu, C. Zhao, J. W. Vickers, Y. Ding, S. Mohebbi, A. E. Kuznetsov, D. G. Musaev, T. Lian, C. L. Hill, Isr. J. Chem. 2011, 51, 238-246; k) Z. Huang, Z. Luo, Y. V. Geletii, J. Vickers, Q. Yin, D. Wu, Y. Hou, Y. Ding, J. Song, D. G. Musaev, C. L. Hill, T. Lian, J. Am. Chem. Soc. 2011, 133, 2068-2071; 1) M Carraro, A. Sartorel, F. M. Toma, F. Puntoriero, F. Scandola, S. Campagna, M. Prato, M. Bonchio, Top. Curr. Chem. 2011, 303, 121$150 ; \mathrm{m})$ M. Murakami, D. Hong, T. Suenobu, S. Yamaguchi, T. Ogura, S. Fukuzumi, J. Am. Chem. Soc. 2011, 133, 11605-11613; n) S. Tanaka, M. Annaka, K. Sakai, Chem. Commun. 2012, 48, 16531655; o) G. Zhu, Y. V. Geletii, P. Kögerler, H. Schilder, J. Song, S. Lense, C. Zhao, K. I. Hardcastle, D. G. Musaev, C. L. Hill, Dalton Trans. 2012, 41, 2084-2090; p) P.-E. Car, M. Guttentag, K. K Baldridge, R. Albertoa, G. R. Patzke, Green Chem. 2012, 14, 16801688; q) M. Natali, M. Orlandi, S. Berardi, S. Campagna, M Bonchio, A. Sartorel, F. Scandola, Inorg. Chem. 2012, 51, 7324 
7331; r) G. Zhu, E. N. Glass, C. Zhao, H. Lv, J. W. Vickers, Y. V. Geletii, D. G. Musaev, J. Song, C. L. Hill, Dalton Trans. 2012, 41 13043-13049; s) S. Goberna-Ferrón, L. Vigara, J. Soriano-López, J. R. Galán-Mascarós, Inorg. Chem. 2012, 51, 11707-11715; t) S. Fukuzumi, D. Hong, Eur. J. Inorg. Chem. 2013, Published Online 08/22/13; u) F. Evangelisti, P.-E. Car, O. Blacque, G. R. Patzke, Catal. Sci. Technol. 2013, 3, 3117-3129; v) J. Soriano-López, S Goberna-Ferrón, L. Vigara, J. J. Carbó, J. M. Poblet, J. R. GalánMascarós, Inorg. Chem. 2013, 52, 4753-4755; w) F. Song, Y. Ding, B. Ma, C. Wang, Q. Wang, X. Du, S. Fu, J. Song, Energy Environ. Sci. 2013, 6, 1170-1184.

[23] a) L. Alaerts, J. Wahlen, P. A. Jacobs, D. E. D. Vos, Chem. Commun 2008, 1727-1737; b) S. Piccinin, A. Sartorel, G. Aquilanti, A Goldoni, M. Bonchio, S. Fabris, Proc. Nat. Acad. Sci. 2013, 110 4917-4922; c) S.-X. Guo, Y. Liu, C.-Y. Lee, A. M. Bond, J. Zhang, Y. V. Geletii, C. L. Hill, Energy Environ. Sci. 2013, 6, 2654-2663; d) F. M. Toma, A. Sartorel, M. Iurlo, M. Carraro, P. Parisse, C. Maccato, S. Rapino, B. R. Gonzalez, H. Amenitsch, T. D. Ros, L. Casalis, A. Goldoni, M. Marcaccio, G. Scorrano, G. Scoles, F. Paolucci, M. Prato, M. Bonchio, Nature Chem. 2010, 2, 826-831; e) M. Quintana, A. M. López, S. Rapino, F. M. Toma, M. Iurlo, M. Carraro, A. Sartorel, C. Maccato, X. Ke, C. Bittencourt, T. Da Ros, G. Van Tendeloo, M. Marcaccio, F. Paolucci, M. Prato, M. Bonchio, ACS Nano 2013, 7, 811-817.

[24] a) C.-Y. Lee, S.-X. Guo, A. F. Murphy, T. McCormac, J. Zhang, A M. Bond, G. Zhu, C. L. Hill, Y. V. Geletii, Inorg. Chem. 2012, 51, 11521-11532; b) X. Lopez, J. J. Carbo, C. Bo, J. M. Poblet, Chem. Soc. Rev. 2012, 41, 7537-7571.

[25] a) Y. Wu, X.-P. Zhou, J.-R. Yang, D. Li, Chem. Commun. 2013, 49 3413-3415; b) H. Dau, C. Limberg, T. Reier, M. Risch, S. Roggan, P Strasser, Chem. Cat. Chem. 2010, 2, 724-761.

[26] a) R. Schiwon, K. Klingan, H. Dau, C. Limberg, Chem. Commun. 2013, ASAP; b) J. J. Stracke, R. G. Finke, ACS Catal. 2014, 4, 79-89.

[27] a) J. W. Vickers, H. Lv, J. M. Sumliner, G. Zhu, Z. Luo, D. G. Musaev, Y. V. Geletii, C. L. Hill, J. Am. Chem. Soc. 2013, 135 14110-14118; b) H. Lv, J. A. Rudd, P. F. Zhuk, J. Y. Lee, E. C Constable, C. E. Housecroft, C. L. Hill, D. G. Musaev, Y. V. Geletii, RSC Adv. 2013, 3, 20647-20654.

[28] a) J. J. Stracke, R. G. Finke, J. Am. Chem. Soc. 2011, 133, 14872 14875; b) J. J. Stracke, R. G. Finke, ACS Catal. 2013, 3, 1209-1219.

[29] a) M. Natali, S. Berardi, A. Sartorel, M. Bonchio, S. Campagna, F. Scandola, Chem. Commun. 2012, 48, 8808-8810; b) C. A. Ohlin, S. J. Harley, J. G. McAlpin, R. K. Hocking, B. Q. Mercado, R. L. Johnson, E. M. Villa, M. K. Fidler, M. M. Olmstead, L. Spiccia, R. D. Britt, W. H. Casey, Chem. Eur. J. 2011, 17, 4408-4417; c) D. Lieb, A Zahl, E. F. Wilson, C. Streb, L. C. Nye, K. Meyer, I. IvanovićBurmazović, Inorg. Chem. 2011, 50, 9053-9058; d) J. Wu, L. Liao, W. Yan, Y. Xue, Y. Sun, X. Yan, Y. Chen, Y. Xie, ChemSusChem 2012, 5, 1207-1212.

[30] D. E. Katsoulis, M. T. Pope, J. Am. Chem. Soc. 1984, 106, $2737-$ 2738

[31] a) Y. Hou, L. Xu, M. J. Cichon, S. Lense, K. I. Hardcastle, C. L. Hill, Inorg. Chem. 2010, 49, 4125-4132; b) H. Lv, J. Song, Y. V. Geletii, W. Guo, J. Bacsa, C. L. Hill, Eur. J. Inorg. Chem. 2013, 2013, 17201725 .

[32] D. R. Lide, 81st. ed., CRC Press, Boca Raton, FL, 2000.

[33] a) Z. Han, F. Qiu, R. Eisenberg, P. L. Holland, T. D. Krauss, Science 2012, 338, 1321-1324; b) M. Kirch, J.-M. Lehn, J.-P. Sauvage, Helv. Chim. Acta 1979, 62, 1345-1384; c) A. J. Bard, M. A. Fox, Acc Chem. Res. 1995, 28, 141-145; d) A. Kudo, Y. Miseki, Chem. Soc Rev. 2009, 38, 253-278; e) H. Lv, L. Ma, P. Zeng, D. Ke, T. Peng, J. Mater. Chem. 2010, 20, 3665-3672; f) H. Zhu, N. Song, H. Lv, C. L. Hill, T. Lian, J. Am. Chem. Soc. 2012, 134, 11701-11708; g) A LeGoff, V. Artero, B. Jousselme, P. D. Tran, N. Guillet, R. Métayé, A. Fihri, S. Palacin, M. Fontecave, Science 2009, 326, 1384-1387.

[34] a) K. Kalyanasundaram, J. Kiwi, M. Grätzel, Helv. Chim. Acta 1978 61, 2720-2730; b) E. D. Cline, S. E. Adamson, S. Bernhard, Inorg. Chem. 2008, 47, 10378-10388; c) P. Du, J. Schneider, P. Jarosz, R. Eisenberg, J. Am. Chem. Soc. 2006, 128, 7726-7727; d) H. Kunkely,
A. Vogler, Angew. Chem. Int. Ed. 2009, 48, 1685-1687; e) J. L. Dempsey, B. S. Brunschwig, J. R. Winkler, H. B. Gray, Acc. Chem. Res. 2009, 42, 1995-2004.

[35] T. Peng, X. Zhang, H. Lv, L. Zan, Catal. Commun. 2012, 28, 116 119.

[36] A. J. Esswein, D. G. Nocera, Chem. Rev. 2007, 107, 4022-4047.

[37] a) A. F. Heyduk, D. C. Nocera, Science 2001, 293, 1639-1641; b) K Yamauchi, S. Masaoka, K. Sakai, J. Am. Chem. Soc. 2009, 131 8404-8406; c) G. S. Bindra, M. Schulz, A. Paul, S. Soman, R Groarke, J. Inglis, M. T. Pryce, W. R. Browne, S. Rau, B. J. Macleand, J. G. Vos, Dalton Trans. 2011, 40, 10812-10814.

[38] a) H. Ozawa, M. Haga, K. Sakai, J. Am. Chem. Soc. 2006, 128 4926-4927; b) J. Zhang, P. Du, J. Schneider, P. Jarosz, R. Eisenberg, J. Am. Chem. Soc. 2007, 129, 7726-7727; c) M. Nielsen, A. Kammer, D. Cozzula, H. Junge, S. Gladiali, M. Beller, Angew. Chem. Int. Ed. 2011, 50, 9593-9597; d) W. M. Singh, D. Pegram, H. Duan, D Kalita, P. Simone, G. L. Emmert, X. Zhao, Angew. Chem. Int. Ed. 2012, 51, 1653-1656.

[39] a) V. Artero, M. Chavarot-Kerlidou, M. Fontecave, Angew. Chem. Int. Ed. 2011, 50, 7238-7266; b) D. G. Nocera, Acc. Chem. Res. 2012, $45,767-776$.

[40] E. N. Savinov, S. S. Saidkhanov, V. N. Parmon, K. I. Zamaraev, React. Kinet. Catal. Lett. 1981, 17, 407-411.

[41] J. R. Darwent, J. Chem. Soc., Chem. Commun. 1982, 14, 798-799.

[42] E. Papaconstantinou, J. Chem. Soc., Chem. Commun. 1982, 12-13.

[43] a) T. Yamase, Inorg. Chim. Acta 1982, 64, L155-L156; b) T. Yamase, Inorg. Chim. Acta 1983, 76, L25-L27; c) R. Akid, J. R. Darwent, J. Chem. Soc., Dalton Trans. 1985, 395-399; d) R. F. Renneke, C. L. Hill, J. Am. Chem. Soc. 1986, 108, 3528-3529; e) C. L. Hill, R. F. Renneke, L. Combs, Tetrahedron 1988, 44, 7499-7507; f) R. F. Renneke, C. L. Hill, Angew. Chem. Int. Ed. 1988, 27, 15261527; g) R. F. Renneke, C. L. Hill, J. Am. Chem. Soc. 1988, 110 , 5461-5470; h) J. Kiwi, M. Grätzel, J. Phys. Chem. 1987, 91, 6673 6677; i) Z. Zhang, Q. Lin, D. Kurunthu, T. Wu, F. Zuo, S.-T. Zheng C. J. Bardeen, X. Bu, P. Feng, J. Am. Chem. Soc. 2011, 133, 6934 6937; j) Z. Zhang, Q. Lin, S.-T. Zheng, X. Bu, P. Feng, Chem. Commun. 2011, 47, 3918-3920; k) P. Huang, C. Qin, Z.-M. Su, Y Xing, X.-L. Wang, K.-Z. Shao, Y.-Q. Lan, E.-B. Wang, J. Am. Chem. Soc. 2012, 134, 14004-14010; 1) T. Yamase, R. Watanabe, J. Chem. Soc., Dalton Trans. 1986, 1669-1675; m) T. Yamase, M. Sugeta Inorg. Chim. Acta 1990, 172, 131-134; n) E. Papaconstantinou, A. Ioannidis, A. Hiskia, P. Argitis, D. Dimotikali, S. Korres, Mol. Eng. 1993, 3, 231-239; o) L. Q. Dang, W. S. You, X. Zhang, C. Y. Huang, Z. B. Lei, Z. G. Sun, C. Li, Chinese Chem. Lett. 2006, 17, 973-976; p) T. Yamase, X. Cao, S. Yazaki, J. Mol. Catal. A: Chem. 2007, 262 119-127.

[44] M. Sadakane, E. Steckhan, Chem. Rev. 1998, 98, 219-238.

[45] B. Matt, J. Fize, J. Moussa, H. Amouri, A. Pereira, V. Artero, G Izzet, A. Proust, Energy Environ. Sci 2013, 6, 1504-1508.

[46] H. Lv, J. Song, H. Zhu, Y. V. Geletii, J. Bacsa, C. Zhao, T. Lian, D. G. Musaev, C. L. Hill, J. Catal. 2013, 307, 48-54.

[47] a) M. Orlandi, R. Argazzi, A. Sartorel, M. Carraro, G. Scorrano, M Bonchio, F. Scandola, Chem. Commun. 2010, 46, 3152-3154; b) Z Huang, Y. V. Geletii, D. G. Musaev, C. L. Hill, L. T., Ind. Eng. Chem. Res. 2012, 51, 11850-11859; c) X. Xiang, J. Fielden, W. Rodríguez-Córdoba, Z. Huang, N. Zhang, Z. Luo, D. G. Musaev, T Lian, C. L. Hill, J. Phys. Chem. C 2013, 117, 918-926.

[48] a) W. J. Youngblood, S.-H. A. Lee, Y. Kobayashi, E. A. HernandezPagan, P. G. Hoertz, T. A. Moore, A. L. Moore, D. Gust, T. E Mallouk, J. Am. Chem. Soc. 2009, 131, 926-927; b) R Brimblecombe, A. Koo, G. C. Dismukes, G. F. Swiegers, L. Spiccia, J. Am. Chem. Soc. 2010, 132, 2892-2894; c) G. F. Moore, J. D. Blakemore, R. L. Milot, J. F. Hull, H.-e. Song, L. Cai, C. A. Schmuttenmaer, R. H. Crabtree, G. W. Brudvig, Energy Environ. Sci. 2011, 4, 2389-2392; d) W. Song, C. R. K. Glasson, H. Luo, K Hanson, M. K. Brennaman, J. J. Concepcion, T. J. Meyer, J. Phys. 
Chem. Lett. 2011, 2, 1808-1813; e) Y. Gao, X. Ding, J. Liu, L. Wang, Z. Lu, L. Li, L. Sun, J. Am. Chem. Soc. 2013, 135, 4219-4222.

[49] S. Pelet, J.-E. Moser, M. Grätzel, J. Phys. Chem. 2000, 104, 17911795.

[50] W. J. Youngblood, S.-H. A. Lee, K. Maeda, T. E. Mallouk, Acc. Chem. Res. 2009, 42, 1966-1973.

[51] A. M. Lapides, D. L. Ashford, K. Hanson, D. A. Torelli, J. L. Templeton, T. J. Meyer, J. Am. Chem. Soc. 2013, 135, 15450-15458.

Received: ((will be filled in by the editorial staff)) Published online: ((will be filled in by the editorial staff)) 


\section{Layout 1:}

Key Topic

Polyoxometalates (POMs) have enjoyed recent success as catalysts in the multi-electron water oxidation and reduction reactions. They have also been incorporated into photoanodes for heterogeneous water oxidation. We address the challenges that remain and highlight upcoming advances in the field.

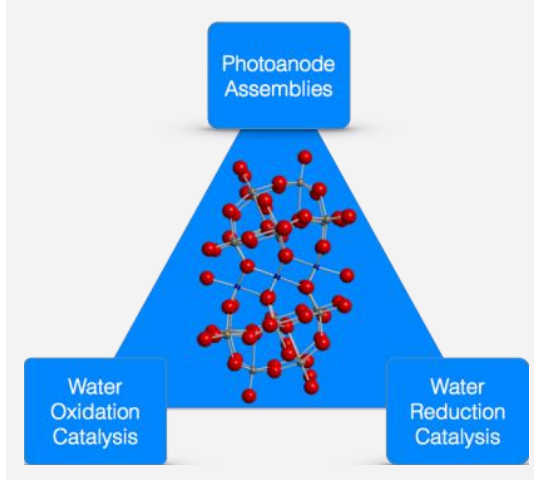

Jordan M. Sumliner, Hongjin Lv, John Fielden, Yurii V. Geletii, and Craig L. Hill* Page No. - Page No.

Polyoxometalate multi-electron transfer catalytic systems for water splitting

Keywords: Polyoxometalates / Water Splitting / Photochemistry / Supported Catalysts 
* EurllC *CChemPubSoc 